\title{
Pengembangan Bahan Ajar Pengembangan APE Berbasis Kewirausahaan S1 PG- PAUD FKIP Universitas Jambi
}

\author{
Nyimas Muazzomi, Hendra Sofyan \\ Pendidikan Guru Anak Usia Dini, FKIP Universitas Jambi
}

\begin{abstract}
ABSTRAK
Bahan ajar merupakan segala bentuk bahan yang digunakan untuk membantu guru/instruktor dalam melaksanakan kegiatan belajar mengajar sehingga peserta didik mudah untuk memahami semua materi yang adalah didalamnya. Berdasarkan obserservasi di PGPAUD FKIP Univeristas Jambi, bahan pembelajaran pada mata kualiah pengembangan Pengembangan APE Berbasis Kewirausahaan belum ada buku secara khusus untuk mata kuliah ini, para dosen dalam mengajar menggunakan beberapa sumber buku yang satu dengan yang lain sehingga membuat para mahasiswa susah dalalam memahami dan mencari buku-buku yang digunakan. Oleh karena itu, maka yang menjadi fokus dalam penelitian ini adalah mengembangkan bahan ajar berupa buku cetak pada mata kuliah pengembangan APE Berbasis Kewirausahaan di PGPAUD FKIP Univeristas Jambi. Hasil kegiatan yang telah di capai dari penelitian ini adalah tersusunnya suatu desain modul pembelajaran mata kuliah Pengembangan APE Berbasis Kewirausahaan untuk mahasiswa S1 PG-PAUD yang telah tervalidasi oleh ahli materi dan media dan respon mahasiswa. Sedang untuk capaian luaran jangka panjang, hasil kegitan ini telah di submit di Jurnal PG-PAUD Universitas Jambi dan modul yang dihasilkan dapat menjadi sumber referensi bagi mahasiswa dan Dosen untuk mengajar mata kuliah Pengembangan APE Berbasis Kewirausahaan.
\end{abstract}

Kata Kunci : Pengembangan, Bahan Ajar,APE ,Kewirausahaan

\section{PENDAHULUAN}

Dalam Undang-undang sisdikanas 2003, Pendidikan nasional berfungsi mengembangkan kemampuan dan membentuk watak serta peradaban bangsa yang bermartabat dalam rangka mencerdaskan kehidupan bangsa, bertujuan untuk berkembangnya potensi peserta didik agar menjadi manusia yang beriman dan bertaqwa kepada Tuhan Yang Maha Esa, berakhlak mulia, sehat, berilmu, cakap, kreatif, mandiri, dan menjadi warga negara yang demokratis serta bertanggung jawab.

Pendidikan merupakan salah satu bidang yang sangat diprioritaskan dalam pembangunan nasional, dan mewujudkan cita-cita untuk mencerdaskan kehidupan bangsa. Beberapa usaha telah dilakukan untuk peningkatan mutu pendidikan, seperti, penataran dosen-dosen, perbaikan metode pembelajaran, perbaikan kurikulum, dan perbaikan sarana prasarana, sumber belajar seperti bahan ajar.

Bahan ajar merupakan segala bentuk bahan yang digunakan untuk membantu guru/instruktor dalam melaksanakan kegiatan belajar mengajar. bahan ajar sanagat berperan dalam meningkatkan kualitas pendidikan karena bahan ajar merupakan salah satu sumber belajar yang dapat digunakan dalam mengalikan ilmu pengatahuan. di dalam bahan ajar tertuang materi-materi yang disusun secara sistematis sehingga mahasiswa mudah untuk memahami semua materi yang adalah didalamnya. namun kenyataan yang ada, masih banyak para dosen, guru maupun istruktor belum memiliki bahan ajar yang sesuai dengan apa yang di ajarkan. sehingga bahan ajar merupakan priorotas dalam menunjang pendidikan 
nasional secara umum dan perguru tinggi secara khususnya. oleh sebab itu perlu dikaji dan dilihat secra menyuruh pada setiap pembelajaran yang dilakukan teutama bahan ajar yang digunakan.

Berdasarkan obserservasi di PGPAUD FKIP Univeristas Jambi, bahan pembelajaran pada mata kualiah pengembangan APE Berbasis Kewirausahaan belum ada buku secara khusus untuk mata kuliah ini, para dosen dalam mengajar menggunakan beberapa sumber buku yang satu dengan yang lain sehingga membuat para mahasiswa susah dalalam memahami dan mencari buku-buku yang digunakan. selain itu, urutan pada materi pada buku yang digunakan belum sitematis sehingga buku tenaga yang ektra dalam memadukan materi yang satu dengan yang lain. kemudian hasil wawancara dengan mahasiswa, selama pembelajaran berlangsung dosen tidak membuat buku atau pedoman khusus dalam menerapkan teori APE . oleh sebab itu dibutuhkan suatu terobosan baru untuk mengatisipai permasalah ini. salah satunya adalah membuat bahan ajar yang sesuai dengan mata kuliah pengembangan APE Berbasis Kewirausahaan .

Berdasarkan permasalahan yang ditemukan diatas, maka penulis mau melakukan penelitian research and development (R\&D) yang berjudulpengembangan Bahan ajar APE Berbasis Kewirausahaan di PGPAUD FKIP Universitas Jambi.

Adapun tujuan dari penelitian ini adalah untuk mengetahui proses pengembangan bahan ajar dan proses pembelajaran mata kuliah pengembangan APE Berbasis Kewirausahaan di PGPAUD FKIP Univeristas Jambi serta mengetahui kevalidavan dan kepraktisan bahan ajar APE Berbasis Kewirausahaan di PGPAUD FKIP Univeristas Jambi.

\section{METODE PENELITIAN}

Desain penelitian yang digunakan pada penelitian ini adalah Research and Development ( $\mathrm{R}$ \& D) yang merupakan rangkaian proses dan langkah-langkah dalam rangka mengembangkan suatu produk baru atau memperbaiki produk-produk yang telah ada agar dapat dipertanggungjawabkan. ini berate bahawa Penelitian R \& D merupakan metode penelitian yang digunakan untuk menghasilkan produk atau menguji keefektifan produk tertentu.

Pada penelitian pengembangan ini adapun lamgkah-langkahnya adalah :

1. Studi Pendahuluan

Studi pendahuluan yang telah dipaparkan bahwa tentang prose pembelajaran yang terjadi di prodi PGPAUD FKIP Unja dan bahan ajar yang digunakan, serta fasilitas yang ada pada tempat penelitian.

2. Perencanaan Pengembangan Bahan ajar

Pengembangan bahan ajar pengembangan APE Berbasis Kewirausahaan dilakukan dengan langkah-langkah:

a. Identifikasi Tujuan pembelajaran (Identity Instructional Goal)

b. Melakukan Analisis Instruksional (Conduct Instructional Analysis)

c. Analisis karakteristik mahasiswa dan kontek pembelajaran (Analyze Learners and Contexts)

3. Mengembangkan penilaian acuan patokan (Develop Assessment Instruments)

4. Mendesain produk, dengan memperhatikan pada tampilan cover, susunan materi, dan hal-hal lainnya.

5. Mengembangkan draf. berdasarkan tindak lanjut apa yang sudah direncanakan. Pada tahap ini pendesain bekerja sama dengan ahli yang dilibatkan untuk mendapatkan tampilan yang dibutuhkan. 
6. Validasi, evaluasi formatif dan revisi.

Pada tahap ini meliputi kegiatan merancang dan melaksanakan penilaian formatif (Design and Conduct Formative Evaluation of Instruction). Ada tiga jenis evaluasi formatif yaitu penilaian satu-satu (one to one expert), penilaian kelompok kecil (small group) dan penilaian uji lapangan (filt test). Setiap jenis penilaian akan memberikan informasi yang berbeda bagi perancang untuk digunakan dalam meningkatkan instruksional.

7. Uji lapangan (field trial) adalah uji coba langsung terhadap bahan pembelajaran yang telah dikembangkan dilakukan kepada 32 orang mahasiswa. Dalam uji coba lapangan ini berfokus pada evaluasi proses dan evaluasi hasil.

Instrumen yang digunakan dalam penelitian ini yaitu lembar penilaian bahan ajar ahli materi, ahli media, ahli desain, dan angket respon smahasiswa. Penyusunan instrumen dilakukan pada tahap perancangan dan evaluasi formatif. Tahap awal model ini adalah menentukan apa yang diinginkan oleh pebelajar atau skill apa yang mereka kehendaki setelah menyelesaikan program Instruksional.

Penelitian ini merupakan penelitian jenis kualitatif dan kuantitatif. Data kualitatif diperoleh dari masukan atau tanggapan dari para ahli dan guru, sedangkan data kuantitatif diperoleh dari data hasil pengisian angket para ahli dan siswa tentang produk bahan ajar yang dikembangkan. Pada analisis deskriptif, data kuantitatif yang diperoleh dicari skor reratanya kemudian dikonversikan ke data kualitatif dengan kriteria penilaian (Widoyoko, 2015:238) kemudian dideskripsikan. Data yang diperoleh tersebut berupa: Skor penilaian dari ahli materi, Skor penilaian dari ahli media, Skor penilaian dari ahli desain,Skor respon siswa.

Tabel 1. Persentase Kelayakan pada Analisis Kevalidan

\begin{tabular}{|c|c|}
\hline Persentase Pencapaian & Interpretasi \\
\hline $76 \%-100 \%$ & Sangat Layak \\
\hline $56 \%-75 \%$ & Layak \\
\hline $40 \%-55 \%$ & Cukup \\
\hline $0 \%-39 \%$ & Kurang Layak \\
\hline
\end{tabular}

Mendeskripsikan persentase kelayakan seluruh aspek terhadap skala penilaian yang dapat ditentukan dengan kriteria yang disajikan pada tabel berikut :

Tabel 2. Persentase Kelayakan pada Analisis Kepraktisan

\begin{tabular}{|c|c|}
\hline Persentase Pencapaian & Interpretasi \\
\hline $76 \%-100 \%$ & Sangat Layak \\
\hline $56 \%-75 \%$ & Layak \\
\hline $40 \%-55 \%$ & Cukup \\
\hline $0 \%-39 \%$ & Kurang Layak \\
\hline
\end{tabular}

Sumber: Arikunto (Purbasari, 2012: 3) 
Kualitas produk bahan ajar yang dikembangkan dapat diketahui, baik dari kualitas aspek kevalidan dan kepraktisan, maka peneliti menggunakan kriteria minimal penilaian yang termasuk kategori "Baik". Jika penilaian bahan ajar minimal mendapatkan nilai "Baik", maka perangkat pembelajaran yang dikembangkan "Layak" dari aspek kevalidan atau dari aspek kepraktisan.

Untuk data kualitatif diperoleh dari masukan atau tanggapan para ahli dan mahasiswa, data-data tersebut dianalisis secara deskriptif kualitatif. Sedangkan menurut (Sugiyono, 2007:147) statistik deskriptif adalah statistik yang digunakan untuk menganalisa data dengan cara mendeskripsikan atau menggambarkan data yang terkumpul sebagaimana adanya tanpa bermaksud membuat kesimpulan yang berlaku untuk umum atau generalisasi. Tanggapan atau masukan dari para ahli dan mahasiswa yang bersifat membangun dan dianggap tepat untuk pengembangan Bahan Ajar yang digunakan sebagai bahan perbaikan pada tahap revisi Bahan Ajar.

\section{HASIL DAN PEMBAHASAN}

Penelitian yang digunakan dalam penelitian ini adalah research and development $(R \& D)$ yang merupakan rangkaian proses dan langkah-langkah dalam rangka mengembangkan suatu produk baru atau memperbaiki produk-produk yang telah ada agar dapat dipertanggungjawabkan. ini beratti bahawa Penelitian R \& D merupakan metode penelitian yang digunakan untuk menghasilkan produk atau menguji keefektifan produk tertentu..

Tujuan pada penelitian pengembangan ini adalah mengembangkan produk baru dan menguji kefektifan produk tersebut. Rancangan penelitian yang digunakan adalah metode penelitian pengembangan dengan produk berupa bahan ajarl untuk mata kuliah Pengembangan APE Berbasis Kewirausahaans yang dapat digunakan sebagai bahan ajar di kelas.

Adapun langkah-langkah penggunaan metode penggunaan metode pengembangan (Research and Development) dalam penelitian ini adalah :

\section{Studi Pendahuluan}

Tahap awal analisis pendahuluan merupakan aktivitas pra rancangan berupa proses pembelajaran yang terjadi di prodi PGPAUD FKIP Universitas Jambi, bahan ajar yang selama ini digunakan, pelaksanaan pembelajaran yang terjadi selama perkuliahan berlangsung.serta fasilitas yang ada pada tempat penelitian. Dalam pelaksanaan kegiatan ini, peneliti di sini bertindak sebagai Dosen Pengampu mata kuliah pengembangan APE Berbasis Kewirausahaan.. Menggunakan buku karangan lain..

\section{Perancangan Pengembangan Bahan Ajar}

Tahap Kedua yang dilakukan dalam penelitian ini adalah perencanaan Pengembangan bahan ajar pengembangan APE Berbasis Kewirausahaan dilakukan dengan langkah-langkah :

a. Identifikasi Tujuan Pembelajaran (Identity Instructional Goal $(s)$ )

Tahap awal model ini adalah menentukan apa yang diinginkan oleh pebelajar atau skill apa yang mereka kehendaki setelah menyelesaikan program Instruksional. pada tahap ini akan menghasilkan kemampuan mahasiswa setelah menyelesaikan pembelajaran mata kuliah pengembangan APE Berbasis Kewirausahaan sesuai dengan karakteristik model yang dikembangkan.

Adapun tujuan pembelajaran yang ingin disampaikan dalam sebuah modul pengembangan bahan ajar untuk mata kuliah APE Berbasis Kewirausahaan ini adalah : 
1) Menjelaskan Latar belakang pentingnya pengembangan alat permainan edukatif pada anak usia

2) Menjelaskan konsep pengembangan alat yang dibuat.

3) Mengembangkan alat permainan edukatif berbasis kewirausahaan

Untuk mencapai tujuan tersebut, materi yang disajikan dalam mata kuliah ini disusun dalam sembilan topik sebagai berikut :

a) Pengertian APE (Alat permainan edukatif )

b) Jenis dan mamfaat APE

c) Kegiatan pengembangan APE Berbasis Kewirausahaan .

b. Melakukan Analisis Instruksional (Conduct Instructional Analysis)

Tujuan umum yang telah dirumuskan dijadikan dasar untuk mengalisis pembelajaran. Analisis pembelajaran merupakan suatu proses menjabarkan perilaku umum yang lebih spesifik yang tersusun secara logis dan sistematis. Langkah ini, mengklasifikasi tujuan ke dalam ranah belajar Gagne berupa kemampuan kognitif, psikomotorik dan afektif.

c. Analisis karakteristik siswa dan kontek pembelajaran (Analyze Learners and Contexts)

PG-PAUD merupakan Program Studi PAUD Universitas Jambi penghasil dan pengembang tenaga pendidikan anak usia dini yang profesional, berkualitas, berkarakter kuat, kreatif, berakar budaya Indonesia dan berlandaskan iman. Maka dalam hal ini mahasiswa PG-PGPAUD tidak hanya belajar nyanyi lagu anak-anak saja namun lebih dari itu.

\section{d. Merumuskan Tujuan Performansi (Write Performance Objectives)}

Tahap ini merupakan penjabaran lebih lanjut dari tujuan umum yang lazimnya dirumuskan dalam satu mata kuliah tertentu. pada tahap ini akan menghasilkan Pernyataan-pernyataan dari keterampilan yang diidentifikasi dalam analisis Instruksional, akan mengidentifikasi keterampilan yang harus dipelajari. kondisi dan keiterian percapaian. jabaran terdiri dari audien (A), behavior (B0, condition (C), dan Degree.:

e. Mengembangkan penilaian acuan patokan (Develop Assessment Instruments)

Tes penilaian acuan patokan dikembangkan untuk mengetahui kemampuan mahasiswa. Tes ini merupakan pengujian untuk mengetahui sejauh mana pengusaan materi yang dikuasai dan sebagai umpan balik bagi mahasiswa dengan menggunakan skala kriteria angka dan huruf.

Pelaporan penilaian berupa kualifikasi keberhasilan mahasiswa dalam menempuh mata kuliah Pengembangan APE Berbasis Kewirausahaan yang dinyatakan dalam kisaran :

Tabel 3. Kriteria Kisaran Nilain Acuan Keberhasilan Penguasaan Materi

\begin{tabular}{|c|c|c|}
\hline $80-100$ & A & 4,0 \\
\hline $77-79$ & A- & 3,75 \\
\hline $75-76,99$ & B + & 3,5 \\
\hline $70-74,99$ & B & 3,0 \\
\hline $67-69,99$ & B- & 2,75 \\
\hline $62-66,99$ & C + & 2,5 \\
\hline $60-62,99$ & C & 2,0 \\
\hline $55-59,99$ & D+ & 1,5 \\
\hline $45-54,99$ & D & 1,0 \\
\hline$\leq 44,99$ & E & 0 \\
\hline
\end{tabular}




\section{f. Mengembangan strategi pembelajaran (Develop Instructional Strategy)}

Penentuan strategi pembelajaran merupakan suatu langkah-langkah yang disusun dalam pembelajaran, pada strategi pembelajaran meliputi kegiatan awal, kegiatan inti dan penutup.

g. Mengembangkan dan memilih materi pembelajaran (Develop and Select Instructional Materials).

Langkah ini merupakan lanjutkan yang harus dilakukan dalam pencapaian tujuan umum yang telah ditetapkan. Materi pembelajaran dalam pengembangan desain ini di sajikan dalam bentuk buku. Pengembangan materi merupakan penjabaran dari tujuan khusus yang telah ditetapkan. Langkah-langkah pengembangan materi tersebut sebagai berikut :

\section{Perescanaan dan analisis kebutuhan}

Tahap ini merupakan pengumpulan data materi bahan pembelajaran. data analisis kebutuhan diperoleh melalui angket dan hasil tersebut dapat dijadikan pedoman dalam merancang desain awal dari produk.

1) Mendesain produk

Mendesain produk harus memperhatikan pada tampilan cover, susunan materi, dan hal-hal lainnya.

2) Mengembangkan draf.

Draf dikembangkan berdasarkan tindak lanjut apa yang sudah direncanakan. Pada tahap ini pendesain bekerja sama dengan ahli yang dilibatkan untuk mendapatkan tampilan yang dibutuhkan.

\section{Merancang dan Melaksanakan Penilaian Formatif (Design and Conduct Formative Evaluation of Instruction).}

Pada tahap ini, penelitian ini hanya sampai pada tahap evalusi formatif. Ada tiga jenis evaluasi formatif yaitu penilaian satu-satu (one to one expert), penilaian kelompok kecil (small group) dan penilaian uji lapangan (filt test). Setiap jenis penilaian akan memberikan informasi yang berbeda bagi perancang untuk digunakan dalam meningkatkan instruksional.

\section{Validasi, evaluasi formatif dan revisi}

Validasi dan evaluasi bertujuan untuk mengetahui kesempurnaan data revisi dan pegembangan bahan pembelajaran. Validasi dan evaluasi formatif ini ditelaah oleh : (1) one to one expert, yakni ahli materi, ahli desain intruksional dan ahli multimedia, (2) one to one learner, yaitu uji coba perorangan yang dilakukan terhadap subjek pengguna yaitu mahasiswa sebagai pemakai, (3) small group, yaitu ujicoba kelompok kecil tentang kesesuaian prinsip-prinsip pembelajaran dengan pripsip penggunaan, (4) field trial, yaitu ujicoba lapangan.

Tahap terakhir dari pengembangan ini adalah evaluasi. Evaluasi dapat di lakukan di setiap tahap pengembangan sebagai bentuk revisi baik pada validasi ahli dan juga respon mahasiswa. Pada hasil respon mahasiswa terhadap kebermanfaatan dan kemudahan bahan ajar 1 dari segi isi dan konsep bahan ajar itu sendiri, tidak memungkinkan terdapat saran dan tambahan yang konstruktivitis dari para mahasiswa sebagai subjek uji coba sehingga dihasilkan produk bahan ajar yang layak dan dapat di implementasikan ke kelas yang lebih besar dan dapat di lihat dampak atau uji pengaruh dari bahan ajar yang dikembangkan.

one to one expert 
Pada telaah pakar ahli materi, peneliti meminta bantuan satu orang dosen pengampu mata kuliah pengembangan APE Berbasis Kewirausahaan, telaah pakar Desain Instruksional peneliti meminta bantuan dosen Teknologi Pendidikan. Telaah Pakar media meminta bantuan seorang pakar IT.

\section{one to one learner}

pada Uji coba perorangan yang dilakukan terhadap subjek pengguna yang dilakukan secara perorangan terhadap tiga orang mahasiswa yang memiliki kemampuan rendah, sedang dan tinggi. Mahasiswa ini merupakan calon user pembelajaran dengan menggunakan instrumen kuesioner, untuk memperoleh masukan mengenai kelengkapan yang ada pada bahan pembelajaran yang nantinya sebagai bahan pertimbangan.

\section{small group}

Pada kelompok kecil atau small group evaluation yang dilakukan terhadap kelompok kecil atau user yang merupakan calon pengguna program pembelajaran yang terdiri dari 9 orang (3 kemampuan rendah, 3 kemampuan sedang dan 3 kemampuan tinggi. Proses ini bertujuan untuk memperoleh masukan terhadap bahan pembelajaran.

\section{Field Trial}

Pada uji lapangan atau field trial adalah uji coba langsung terhadap bahan pembelajaran yang telah dikembangkan dilakukan kepada 32 orang mahasiswa. Dalam uji coba lapangan ini berfokus pada evaluasi proses dan evaluasi hasil.

\section{Revisi Instruksional (Revise Instruction).}

Revisi harus dilakukan secara terus menerus dalam setiap validasi yang dilakukan. Pada tahap ini data yang didapat sebelumnya dianalisis dan dilakukan revisi dalam bentuk perbaikan-perbaikan sesuai dengan saran yang diberikan dalam setiap tahap evaluasi formatif.

Hasil kegiatan yang telah di capai dari penelitian ini adalah tersusunnya suatu desain bahan ajar pembelajaran mata kuliah Pengembangan APE Berbasis Kewirausahaan untuk mahasiswa S1 PG-PAUD yang telah tervalidasi oleh ahli materi dan media dan respon mahasiswa. Sedang untuk capaian luaran jangka panjang, hasil kegitan ini telah di submit di Jurnal PG-PAUD Universitas Jambi dan bahan ajar yang dihasilkan dapat menjadi sumber referensi bagi mahasiswa dan Dosen untuk mengajar mata kuliah Pengembangan APE Berbasis Kewirausahaan..

\section{KESIMPULAN DAN SARAN}

Berdasarkan hasil penelitian pengembangan dan pembahasan tentang pengembangan dengan bahan ajar berupa bahan ajar mata kuliah Pengembangan APE Berbasis Kewirausahaan untuk mahasiswa S1 PG-PAUD, maka dapat di tarik kesimpulan sebagai berikut : Penelitian ini merupakan penelitian pengembangan metode Research and Development yang terdiri dari 4 tahap yaitu potensi masalah, pengumpulan data, desian produk, validasi desain, revisi, uji coba dan produk final. Namun dalam penelitian ini dikarenakan terkendala oleh waktu, maka proses pengembangan masih dalam tahap uji coba. Beberapa saran yang dapat disampaikan dalam hal ini adalah perlu penelitian serupa berbentuk e-learning yang lebih interaktif untuk mata kuliah Pengembangan APE Berbasis Kewirausahaan dan juga untuk mata kuliah lainnya. 


\section{DAFTAR PUSTAKA}

Alat permainan edukatif menurut Direktorat PAUD.

Direktorat PADU. 2003. Model PADU terintegrasi posyandu. Jakarta : Direktorat PADU. Ditjen PLSP Depdiknas.

Eman Suherman.2008. Desain Pembelajaran Kewirausahaan, Bandung: Alfabeta Hijriati. (2017). Peranan Dan Manfaat Ape Untuk Mendukung Kreativitas Anak Usia

Dini. Volume III (2). 59-69

Jurnal : Identifikasi pemanfaatan alat permainan edukatif (APE) dalam mengembangkan motorik halus anak usia dini.

Jurnal ilmiah universitas Batanghari jambi : pengembangan alat permainan edukatif pendidikan anak usia dini melalui aplikasi Microsoft powerpoint (nyimas muazzomi).

Jurnal psikologi tabularasa : efektivitas alat permainan edukatif (APE) Berbasis media dalam meningkatkan kemampuan berhitung pada anak kelas 2 di SDN 2 wonotirto bulu temanggung.

Jurnal UIN Ar Raniry(Peranan dan Manfaat APE untuk Mendukung Kreativitas Anak Usia Dini) oleh HIJRIATI Tahun 2017

Kasmir.2013. Kewirausahaan-Edisi Revisi, Jakarta: PT Rajagrafindo Persada Keputusan

961/KEP/M/XI/1995

Menteri Koperasi dan Pembinaan Pengusaha Kecil Nomor

Khobir. A. 2009. Upaya Mendidik Anak Melalui Permainan Edukatif. Forum Tarbiyah. Vol. 7 No. 2. STAIN Pekalongan.

Layla Maghfiroh, Permainan Edukatif dalam Pembelajaran Anak di TK Terpadu Tarbiyatul Athfal Jepara, (Yogyakarta: UIN SUKA, 2010), h .57. /Skripsi, Fak. Tarbiyah, Jur PAI.

Suryadi. 2007. Cara Efektif Memahami Perilaku Anak Usia Dini. Jakarta. Penerbit EDSA Mahkota

Syamsuardi. (2012). Penggunaan Alat Permainan Edukatif (Ape) Di Taman Kanak- Kanak Paud Polewali Kecamatan Tanete Riattang Barat Kabupaten Bone. Jurnal Publikasi Pendidikan. 11(1). 59-67

Yuyus Suryana dan Kartib Bayu.2010. Pendekatan Karakteristik Wirausahawan Sukses. Jakarta: Kencana Prenada Media Group 